\title{
Cloning and Amplified Expression in Streptomyces lividans of the Gene Encoding the Extracellular $\beta$-Lactamase from Streptomyces cacaoi
}

\author{
By MAURO V. LENZINI, ${ }^{1}$ SHIGEO NOJIMA, ${ }^{2}$ JEAN DUSART, ${ }^{1}$ * \\ HIROSHI OGAWARA, ${ }^{2}$ PHILIPPE DEHOTTAY, ${ }^{1}$ JEAN-MARIE FRERE ${ }^{1}$ \\ AND JEAN-MARIE GHUYSEN ${ }^{1}$ \\ ${ }^{1}$ Service de Microbiologie, Université de Liège, Institut de Chimie, B6, B-4000 Sart Tilman, \\ Liège, Belgium \\ ${ }^{2}$ Department of Biochemistry, Meiji College of Pharmacy, Nozawa-1, Setagaya-ku, Tokyo 154, \\ Japan
}

(Received 15 April 1987; revised 10 June 1987)

\begin{abstract}
A $19 \mathrm{~kb}$ SphI DNA fragment containing the gene for the extracellular active-site serine $\beta$-lactamase of Streptomyces cacaoi K CC-SO352 was cloned in Streptomyces lividans TK 24 using the high-copy-number plasmid pIJ702 as vector. A 30 -fold higher yield of $\beta$-lactamase was obtained from $S$. lividans strain ML1, carrying the recombinant plasmid pDML51, than from $S$. cacaoi grown under optimal production conditions. In all respects (molecular mass, isoelectric point, kinetics of inhibition by $\beta$-iodopenicillanate) the overproduced $S$. lividans $\mathrm{ML1}$ $\beta$-lactamase was identical to the original $S$. cacaoi enzyme. A considerable reduction of $\beta$-lactamase production was caused by elimination of a $12.8 \mathrm{~kb}$ portion of the $19 \mathrm{~kb}$ DNA fragment by cleavage at an internal $S p h \mathrm{I}$ site located more than $3 \mathrm{~kb}$ upstream of the $\beta$-lactamase structural gene. The $\beta$-lactamase gene was located within a $1.8 \mathrm{NcoI}-\mathrm{Bcl}$ I fragment but when this fragment was cloned in $S$. lividans pIJ702, the resulting strain produced hardly any more $\beta$-lactamase than the original $S$. cacaoi.
\end{abstract}

\section{INTRODUCTION}

Active-site serine $\beta$-lactamases (EC 3.5.2.6) and active-site serine DD-peptidases (EC number not attributed) react with $\beta$-lactam antibiotics by an acyl enzyme mechanism that involves formation of a serine ester-linked penicilloyl (cephalosporoyl, etc.) enzyme derivative. In most cases, the acyl enzyme formed with the $\beta$-lactamases is very short-lived so that the reaction flux rapidly proceeds to product. With the DD-peptidases, the acyl enzyme is very longlived so that the DD-peptidases become immobilized in an inactive form for a long time; they therefore behave as penicillin-binding proteins (Ghuysen et al., 1984). Questions about the structures and functions of these two classes of $\beta$-lactam antibiotic-recognizing enzymes are being investigated by using a battery of techniques such as X-ray crystallography, kinetic and spectroscopic studies, amino acid sequencing, gene analysis and site-directed mutagenesis. The extracellular active-site serine $\beta$-lactamases produced by Bacillus licheniformis, Bacillus cereus and Streptomyces albus G, and the extracellular active-site serine DD-peptidase of Streptomyces R61, are unrelated in their primary structures but, nevertheless, show striking similarities in the spatial disposition of their secondary structure elements ( $\alpha$-helices and $\beta$-strands), suggesting a close evolutionary relationship (Kelly et al., 1986; Samraoui et al., 1986; O. Dideberg and coworkers, unpublished results). The Streptomyces R61 DD-peptidase gene was cloned and amplified in Streptomyces lividans on plasmid pIJ702 (Duez et al., 1987). In parallel to this, the same host-vector system was used to study Streptomyces $\beta$-lactamase genes. Following previous reports on the $\beta$-lactamase gene of Streptomyces albus $\mathrm{G}$ (Dehottay et al., 1986, 1987) this paper 
describes the cloning of the gene that codes for the $\beta$-lactamase of Streptomyces cacaoi. The biochemical and kinetic properties of this $\beta$-lactamase were described by Ogawara (1975), Ogawara et al. (1981) and Lenzini \& Frère (1985).

\section{METHODS}

Bacterial strains and plasmids. Streptomyces lividans TK24 (str-6) (Hopwood et al., 1983), Streptomyces coelicolor A3(2) and Streptomyces plasmid vector pIJ702 (Katzet al., 1983) were gifts from D. A. Hopwood and T. Kieser of the John Innes Institute, Norwich, UK. Streptomyces cacaoi KCC-SO352 was obtained from A. Seino, Kaken Chemical Co. Ltd, Tokyo, Japan. Streptomyces albus G, Streptomyces R61 and Actinomadura R39 were from the Microbiology Department of the University of Liège. Escherichia coli HBl01 (Boyer \& Roulland-Dussoix, 1969) and plasmid vector pBR322 (Bolivar et al., 1977) were also used.

Media and growth conditions. Growth of Streptomyces cultures was at $28^{\circ} \mathrm{C}$ in YEME medium (Hopwood et al., 1985 ) with vigorous orbital shaking (New Brunswick G25 shaker, 300 r.p.m.). The following liquid media were also used: (i) P medium (Okanishi et al., 1974) supplemented with $0.5 \%$ yeast extract; (ii) Oxoid Mueller-Hinton broth; (iii) Lennox broth (Lennox, 1955); (iv) Merck peptone broth; and (v) E9 broth (Dehottay et al., 1986). R2YE agar (Hopwood et al., 1985) was used for maintenance and plating of Streptomyces strains. E. coli was grown at $37^{\circ} \mathrm{C}$ in Luria-Bertani or M9 medium (Maniatis et al., 1982) with vigorous orbital shaking (see above).

Recombinant DNA techniques. Preparation of Streptomyces chromosomal and plasmid DNA and transformation of Streptomyces protoplasts were done as described by Hopwood et al. (1985). Treatment with restriction endonucleases or Klenow fragment, separation of the digested products by agarose gel electrophoresis, treatment with alkaline phosphatase, and ligation experiments were performed as described by Maniatis et al. (1982). Elution of the DNA fragments from the gels (Dretzen et al., 1981). ${ }^{32}$ P-labelling by nick translation (Maniatis $e t$ al., 1975), hybridization experiments (Southern, 1975), addition of Bg/II linkers (Maniatis et al., 1982), and isoelectric focusing (Righetti \& Drysdale, 1971) were done as described in the relevant references.

Enzymes and antibiotics. The enzymes used in recombinant DNA techniques were from Bethesda Research Laboratories, Boehringer Mannheim, Amersham or Sigma. The antibiotics were from Sigma except for nitrocefin (BBL Microbiology Systems), thiostrepton (a gift from S. J. Lucania, Squibb \& Sons, New Brunswick, NJ, USA) and $\beta$-iodopenicillanate (a gift from J. Kemp, Pfizer Central Research, Sandwich, UK).

$\beta$-Lactamase activity. Nitrocefin was used as substrate. The $\beta$-lactamase activity of Streptomyces liquid culture supernatants was estimated ( $0^{\circ}$ Callaghan et al., 1972) by incubating samples for $1 \mathrm{~h}$ at $30^{\circ} \mathrm{C}$ with $100 \mu \mathrm{M}$ nitrocefin $(500 \mu \mathrm{l}$ final volume $)$ in $50 \mathrm{~mm}$-sodium phosphate $\mathrm{pH} \mathrm{7.0.} \mathrm{An} \mathrm{increase} \mathrm{of} \mathrm{one} \mathrm{absorbance} \mathrm{unit} \mathrm{at} 488 \mathrm{~nm}$ corresponded to $4.5 \mathrm{ng}$ enzyme (Lenzini \& Frère, 1985; and unpublished results). $\beta$-Lactamase-producing Streptomyces colonies grown on R2YE agar plates were detected on the basis of the red halo that they developed on exposure to nitrocefin (Dehottay et al., 1986).

\section{RESULTS AND DISCUSSION}

\section{Cloning of the $\beta$-lactamase gene from $S$. cacaoi}

Fig. 1 shows the restriction maps of the $S$. cacaoi chromosomal DNA fragments used in the experiments described below, and the various derivatives of pIJ702 in which these fragments were inserted. pIJ 702 carries a thiostrepton-resistance marker $(t s r)$ and a tyrosinase-encoding gene (mel) which offers three unique restriction sites for insertional inactivation.

Chromosomal DNA from $S$. cacaoi was fully digested with $B g l \mathrm{II}, S p h \mathrm{I}$ or $S s t \mathrm{I}$ and the unfractionated digests were used in shotgun cloning experiments. Shotgun cloning using the SphI site of the high-copy-number Streptomyces plasmid pIJ702 led to the isolation of one $\beta$-lactamase-producing colony, among 3000 melanin-negative, thiostrepton-resistant $S$. lividans TK24 transformants. The resulting plasmid contained a $19 \mathrm{~kb}$ insert; it was called pDML51 and the strain bearing it was called $S$. lividans ML1. SphI digestion of pDML51 not only regenerated the $5.8 \mathrm{~kb}$ pIJ 702 and the $19 \mathrm{~kb}$ insert but also produced two other fragments of 6.6 and $12.4 \mathrm{~kb}$. Time-course experiments showed that these fragments originated by cleavage of an additional $S p h$ I site of relatively low susceptibility in the $19 \mathrm{~kb}$ insert. Each fragment was recloned into pIJ702 using the $S p h I$ sites as above. $\beta$-Lactamase activity was associated only with the $6.6 \mathrm{~kb}$ fragment. The plasmid with this $6.6 \mathrm{~kb}$ insert was called pDML52 and the strain bearing it was called S. lividans ML2.

The $6.6 \mathrm{~kb}$ fragment containing the $\beta$-lactamase gene was inserted into the $S p h \mathrm{I}$ site of pBR322 and the recombinant plasmid pDML72 was isolated from ampicillin-resistant, 


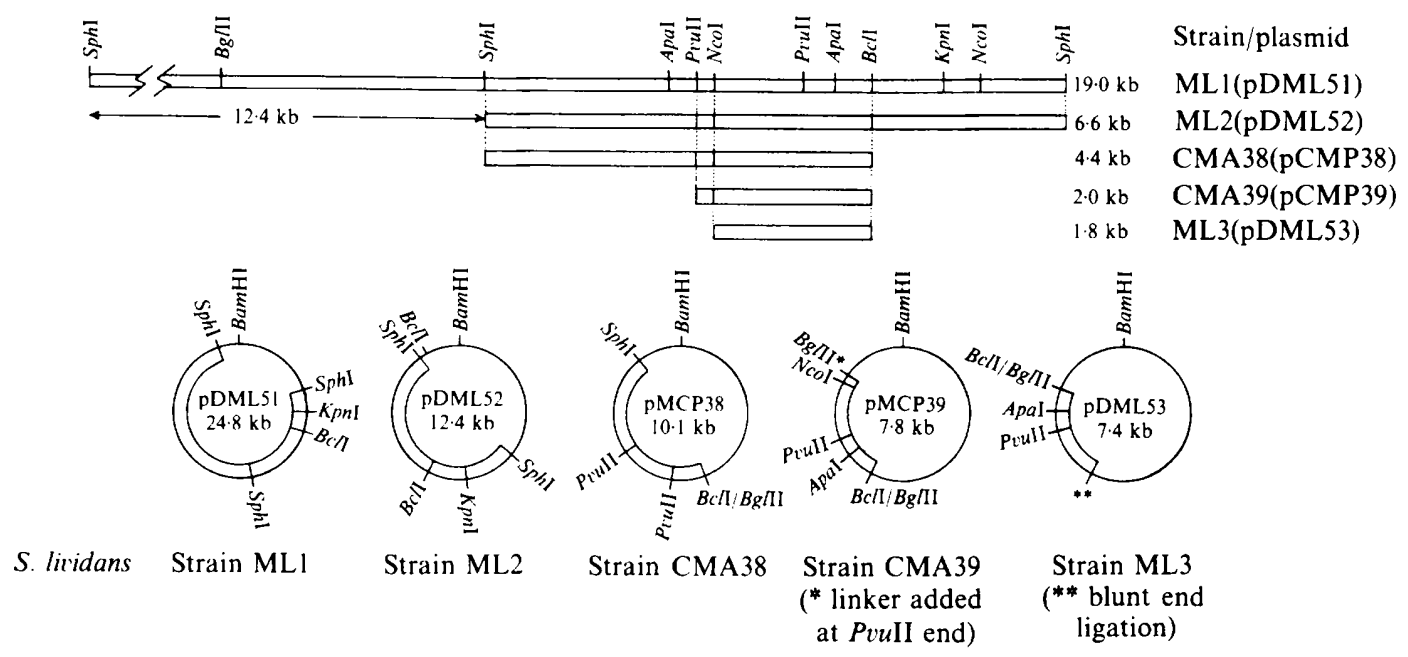

Fig. 1. Restriction maps and cloning in pIJ702 of chromosomal DNA fragments carrying the $S$. cacaoi $\beta$-lactamase gene. (Plasmids are not drawn to scale.) The restriction map was derived from pMCP38 and pBR322-derived pDML72 (not shown; see text).

tetracycline-sensitive $E$. coli $\mathrm{HB} 101$ transformants. pDML72 was ${ }^{32}$ P-labelled by nicktranslation and used as a probe in hybridization experiments against $S p h \mathrm{I}$ digests of chromosomal DNAs from the $\beta$-lactamase-producing Actinomadura R39, $S$. coelicolor, $S$. albus $\mathrm{G}$ and $S$. cacaoi and the $\beta$-lactamase-non-producing or very poorly producing Streptomyces $\mathrm{R} 61$ and $S$. lividans TK24. Hybridization occurred only with the $S$. cacaoi $6.6 \mathrm{~kb}$ fragment and the pDML51 and pDML52 digests (Fig. 2). With the $S$. cacaoi DNA SphI digest used for the shotgun cloning, two hybridization bands $(6.6$ and $19 \mathrm{~kb})$ were observed, indicating incomplete digestion (not shown).

pDML52 was also used to prepare smaller DNA fragments containing the $\beta$-lactamase gene (Fig. 1). Three constructions were made. (i) pDML52 was cut with $B c l$ I and $S p h I$ and the $4.4 \mathrm{~kb}$ fragment thus produced was isolated and ligated to pIJ702 restricted with $B g / \mathrm{II}$ and $S p h \mathrm{I}$ to produce pMCP38 (in S. lividans strain CMA38). (ii) pDML52 was cut with $B c l$ I and the $4.7 \mathrm{~kb}$ fragment thus produced was in turn partially digested with $P v u I I$ with generation of a $2 \mathrm{~kb}$ fragment. After addition of $B g I I I$ linkers, this fragment was ligated to pIJ 702 cut with $B g / I I$ and treated with bacterial alkaline phosphatase to produce pMCP39 (in S. lividans strain CMA39). (iii) Cleavage of pDML52 with $B c l$ I and $N c o I$ generated a $1.8 \mathrm{~kb}$ fragment and cleavage of pIJ 702 with $B g l \mathrm{II}$ and $S s t \mathrm{I}$ generated a $5.5 \mathrm{~kb}$ fragment. These fragments were ligated to give rise to a $7.3 \mathrm{~kb} \mathrm{NcoI}-S s t \mathrm{I}$ linear fragment. After treatment of the $N c o I$ and $S s t \mathrm{I}$ ends by the Klenow fragment of $E$. coli DNA polymerase I, blunt-end ligation yielded the $7 \cdot 3 \mathrm{~kb}$ plasmid pDML53 (in $S$. lividans strain ML3).

Strains CMA38, CMA39 and ML3 gave, to varying extents, a positive nitrocefin test on R2YE agar. However, as shown below, the abilities of these strains to produce extracellular $\beta$-lactamase in liquid media were very different.

\section{Expression and properties of the extracellular $\beta$-lactamase of S. lividans $M L 1$}

$S$. lividans $\mathrm{MLI}$ was grown in various liquid media and the $\beta$-lactamase activity of the culture filtrates was estimated. The following data are mean values of two independent experiments, the observed variations being less than $10 \%$. Maximal production, $38 \mathrm{mg}^{2}$ enzyme $\mathrm{l}^{-1}$, occurred in E9 broth after 3-4 d growth at $28^{\circ} \mathrm{C}$. The yields were $16-17 \mathrm{mg} \mathrm{l}^{-1}$ in $\mathrm{P}$ medium and Lennox broth, $12 \mathrm{mg} \mathrm{l}^{-1}$ in YEME, $9 \mathrm{mg} \mathrm{l}^{-1}$ in Merck peptone broth and $6 \mathrm{mg} \mathrm{l}^{-1}$ in Oxoid Mueller-Hinton broth. With $S$. cacaoi KCC-SO352, production was also maximal in E9 broth $\left(1.4 \mathrm{mg}^{-1}\right)$. 


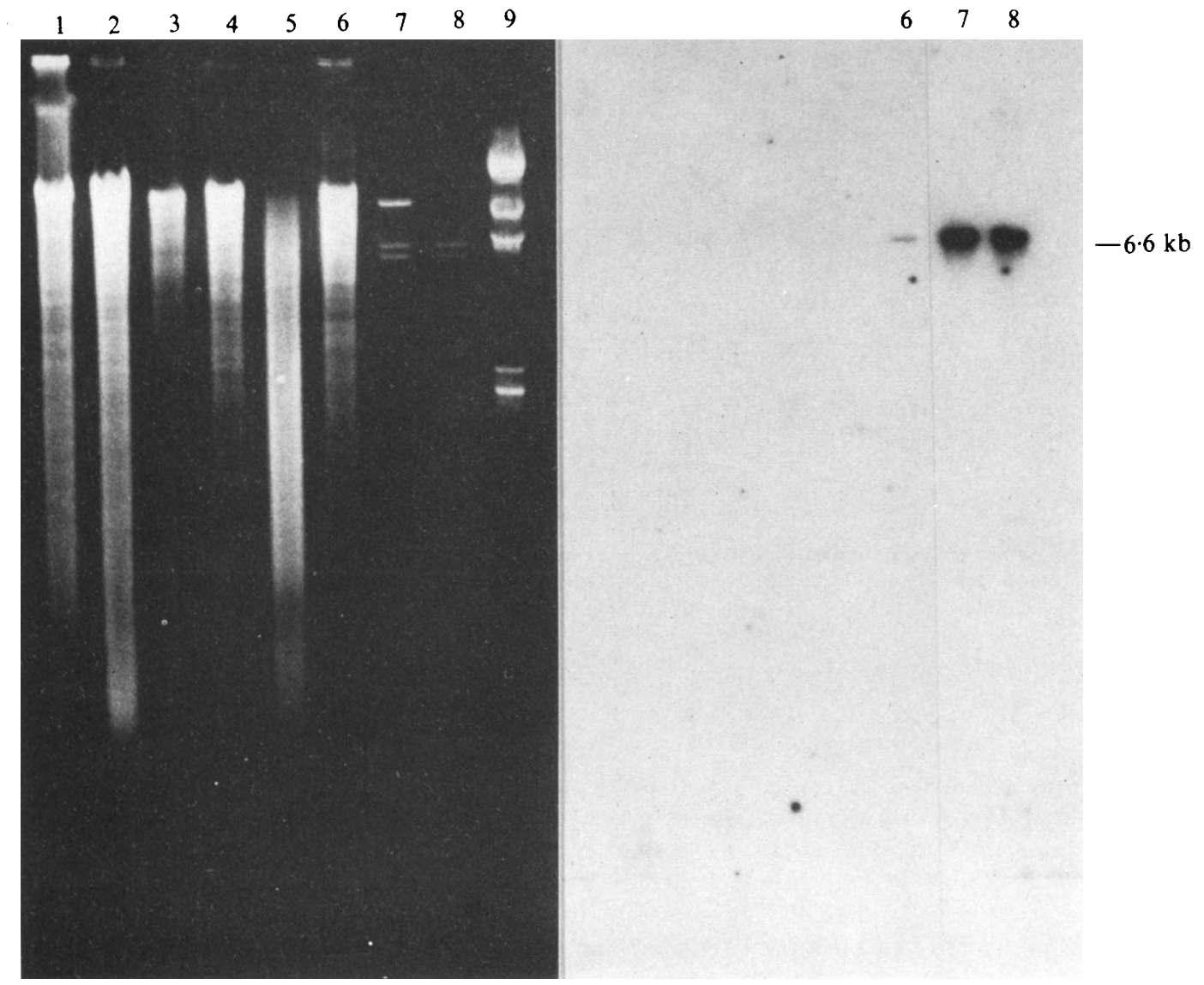

Fig. 2. Hybridization experiments using ${ }^{32} \mathrm{P}$-labelled pDML72 as probe against: (i) SphI-digested DNAs from Actinomadura R39 (lane 1), S. albus G (lane 2), S. lividans TK24 (lane 3), S. coelicolor (lane 4), Streptomyces R61 (lane 5) and $S$. cacaoi (lane 6); and (ii) SphI-digested pDML51 (lane 7) and pDML52 (lane 8). Lane 9: HindIII-digested $\lambda$ DNA.

Hence, $S$. lividans ML1 was a better $\beta$-lactamase producer than $S$. cacaoi, with a 30 -fold increase in enzyme excretion observed under optimal conditions (though an effect of the medium on enzyme excretion could not be excluded; Dehottay et al., 1986).

The extracellular $\beta$-lactamase of $S$. lividans ML1 grown in E9 medium was purified to protein homogeneity (specific activity $575 \mu \mathrm{mol} \mathrm{min}^{-1} \mathrm{mg}_{\text {protein }}^{-1}$ ) using the procedure described for the $S$. cacaoi enzyme. Not only the behaviour of the $S$. lividans MLl $\beta$-lactamase at each step of the purification but the molecular mass $(34 \mathrm{kDa}$ as revealed by SDS-polyacrylamide gel electrophoresis), isoelectric point (4.95), and kinetics of inhibition by $\beta$-iodopenicillanate of the purified enzyme were exactly those expected from the known properties of the $S$. cacaoi $\beta$-lactamase. Moreover, the two enzymes co-eluted by MonoQ FPLC chromatography.

Sub-cloning experiments (see Fig. 1) showed that the $\beta$-lactamase gene was associated with a $1.8 \mathrm{~kb} \mathrm{NcoI}-\mathrm{Bcl}$ I fragment (with the coding region starting close to the $\mathrm{NcoI}$ site; unpublished data). However, all these sub-clones resulted in $S$. lividans strains that had a much decreased capacity to produce the extracellular $\beta$-lactamase (Table 1, Fig. 3). In particular, cleavage of the original $19 \mathrm{~kb}$ DNA fragment at the internal $S p h \mathrm{I}$ site about $3 \mathrm{~kb}$ upstream of the $\beta$-lactamase structural gene (strain ML2) had a drastic effect, suggesting that the eliminated $12.4 \mathrm{~kb}$ segment had important information for $\beta$-lactamase gene expression (and/or enzyme secretion). It should be noted that the observed decreased yields in excreted enzyme by the sub-clones did not relate 


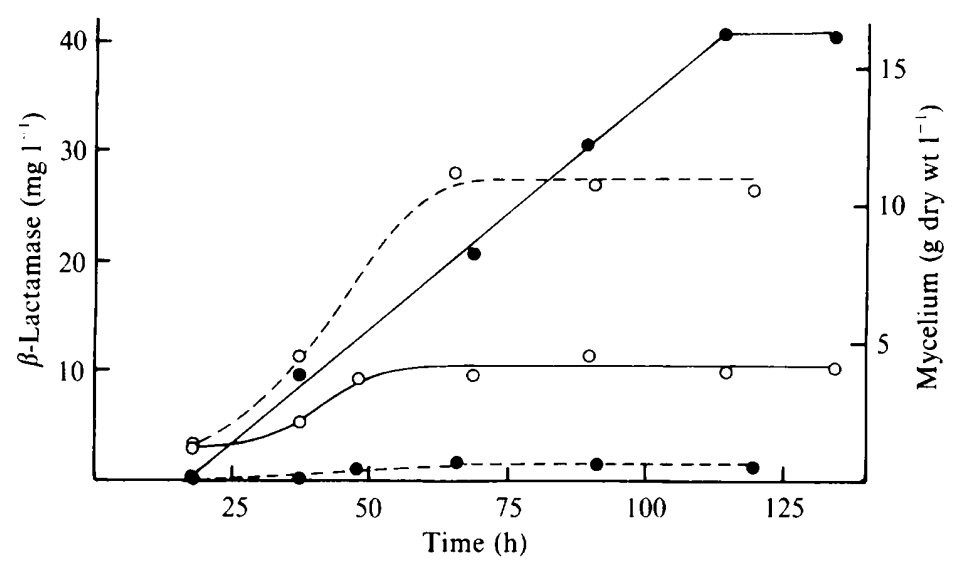

Fig. 3. Growth $(\bigcirc)$ and $\beta$-lactamase excretion $(O)$ of $S$. lividans $\mathrm{ML1}(-)$ and $S$. cacaoi $(----)$ grown in medium $\mathrm{E} 9$ at $28^{\circ} \mathrm{C}$.

Table 1. Maximal levels of $\beta$-lactamase excretion in medium E9 by $S$. lividans carrying various recombinant plasmids and by S. cacaoi KCC-SO352

\begin{tabular}{|c|c|c|c|}
\hline Strain/plasmid & $\begin{array}{c}\text { Size of } S . \text { cacaoi } \\
\text { DNA insert } \\
(\mathbf{k b})\end{array}$ & $\begin{array}{c}\text { Mycelium } \\
\text { (g dry wt } 1^{-1} \text { ) }\end{array}$ & $\begin{array}{c}\text { Extracellular } \\
\beta \text {-lactamase } \\
\left(\mathrm{mg} \mathrm{l}^{-1}\right)\end{array}$ \\
\hline $\begin{array}{l}\text { S. lividans } \mathrm{ML1} / \mathrm{pDML51} \\
\text { ML2/pDML52 } \\
\text { CMA38/pMCP38 } \\
\text { CMA39/pMCP39 } \\
\text { ML3/pDML53 } \\
\text { TK24/- }\end{array}$ & $\begin{array}{c}19 \\
6 \cdot 6 \\
4 \cdot 4 \\
2 \cdot 0 \\
1 \cdot 8 \\
-\end{array}$ & $\begin{array}{l}4 \cdot 6 \\
4 \cdot 5 \\
6 \cdot 6 \\
5 \cdot 2 \\
4 \cdot 6 \\
4 \cdot 4\end{array}$ & $\begin{array}{l}41 \\
8 \cdot 4 \\
4 \cdot 8 \\
1 \cdot 8 \\
0 \cdot 14 \\
\text { ND }\end{array}$ \\
\hline S. cacaoi KCC-SO352/- & - & $11 \cdot 2$ & $1 \cdot 6$ \\
\hline
\end{tabular}

ND, Not detectable.

to variation in the amounts of mycelium produced (Table 1) nor to instability and/or integrity of the plasmids (data not shown). Selection for the plasmids by thiostrepton was applied in all cases (except with $S$. lividans TK24 and $S$. cacaoi KCC-SO352) and the plasmids were found to have conserved their insert (at least after $3 \mathrm{~d}$ growth). However, the possible effects of plasmid copy number and growth rates (as opposed to growth yield) in strains containing the subclones have not been assessed; these factors cannot be entirely discounted, since they could potentially influence $\beta$-lactamase production.

We are grateful to Professor D. A. Hopwood for his helpful advice during the preparation of the manuscript. The work was supported by the Fonds de Recherche de la Faculté de Médecine, the Fonds de la Recherche Scientifique Médicale, Brussels (contract no. 3.4507.83), the Belgian Government (action concertée no. 86/91-90) and the Région wallonne (C2/C16/CONV.246/20428). J.D. is Chercheur qualifié of the Fonds National de la Recherche Scientifique (FNRS). M.V.L. and P.D. are indebted to the Ministère de l'Emploi et du Travail for a Cadre spécial temporaire.

This paper is part of a dissertation of M.V.L. presented as partial fulfilment for a PhD thesis at the University of Liège. 


\section{REFERENCES}

Bolivar, F., Rodriguez, R. L., Greene, P. J., Betlach, M. C., Heyneker, H. L., Boyer, H. W., Crosa, J. H. \& FaLkow, S. (1977). Construction and characterization of new cloning vehicles. II. A multipurpose cloning system. Gene 2, 95-113.

BOYER, H. W. \& Roulland-DussoIX, D. (1969). A complementation analysis of the restriction and modification of DNA in Escherichia coli. Journal of Molecular Biology 41, 459-472.

Dehottay, P., Dusart, J., Duez, C., Lenzini, M. V., Martial, J. A., Frere, J. M., Ghuysen, J. M. \& KIESER, T. (1986). Cloning and amplified expression in Streptomyces lividans of a gene encoding extracellular $\beta$-lactamase from Streptomyces albus G. Gene 42, 31-36.

Dehottay, P., Dusart, J., De Meester, F., Joris, B., van Beeumen, J., Erpicum, T., Frere, J. M. \& GHUYSEN, J. M. (1987). Nucleotide sequence of the gene encoding the Streptomyces albus $\mathrm{G} \beta$-lactamase precursor. European Journal of Biochemistry 166, 345-350.

Dretzen, G., Bellard, M., Sassone-Corsi, P. \& Chambon, P. (1981). A reliable method for the recovery of DNA fragments from agarose and acrylamide gels. Analytical Biochemistry 112, 295298.

Duez, C., Piron-Fraipont, C., Joris, B., Dusart, J., Urdea, M. S., Martial, J. A., Frere, J. M. \& GhuYsen, J. M. (1987). Primary structure of the Streptomyces R61 extracellular DD-peptidase. 1. Cloning into Streptomyces lividans and nucleotide sequence of the gene. European Journal of Biochemistry 162, 509-518.

Ghuysen, J. M., Frere, J. M., Leyh-Bouille, M., Nguyen-Disteche, M., Coyette, J., Dusart, J., Joris, B., Duez, C., Dideberg, O., Charlier, P., Dive, G. \& LAMOTTE-BRASSEUR, J. (1984). Bacterial wall peptidoglycan, DD-peptidases and $\beta$-lactam antibiotics. Scandinavian Journal of Infectious Diseases, suppl. 42, 17-37.

HopwoOd, D. A., Kieser, T., Wright, H. M.\& BibB, M. J. (1983). Plasmids, recombination and chromosome mapping in Streptomyces lividans 66. Journal of General Microbiology 129, 2257-2269.

Hopwood, D. A., BibB, M. J., Chater, K. F., Kieser, T., Bruton, C. J., Kieser, H. M., Lydiate, D. J., SMITH, C. P., WARD, J. M. \& SChrempF, H. (1985). Genetic Manipulation of Streptomyces. A Laboratory Manual. Norwich, UK: John Innes Foundation.

KaTZ, E., Thompson, C. J. \& Hopwood, D. A. (1983). Cloning and expression of the tyrosinase gene from Streptomyces antibioticus in Streptomyces lividans. Journal of General Microbiology 129, 2703-2714.
Kelly, J. A., Dideberg, O., Charlier, P., Wery, J. P., Libert, M., Moews, P. C., Knox, J. R., Duez, C., Fraipont, C., Joris, B., Dusart, J., Frere, J. M. \& GHUYSEN, J. M. (1986). On the origin of bacterial resistance to penicillin: comparison of a $\beta$ lactamase and a penicillin target. Science 231, 14291431.

LENNOX, E. S. (1955). Transduction of linked genetic characters of the host by bacteriophage P1. Virology 1, 190-206.

Lenzini, M. V. \& Frere, J. M. (1985). The $\beta$ lactamase of Streptomyces cacaoi : interaction with cefoxitin and $\beta$-iodopenicillanate. Journal of Enzyme Inhibition 1, 25-34.

Maniatis, J., Jeffrey, A. \& Kleid, D. G. (1975). Nucleotide sequence of the rightward operator of phage $\lambda$. Proceedings of the National Academy of Sciences of the United States of America 72, 11841188.

Maniatis, T., Fritsch, E. F. \& Sambrook, J. (1982). Molecular Cloning: a Laboratory Manual. Cold Spring Harbor, NY: Cold Spring Harbor Laboratory.

O'Callaghan, C. H., Morris, A., Kirby, S. M. \& Shingler, A. H. (1972). Novel method for detection of $\beta$-lactamases by using a chromogenic cephalosporin substrate. Antimicrobial Agents and Chemotherapy 1, 283-288.

Ogawara, H. (1975). Production and properties of $\beta$ lactamases in Streptomyces. Antimicrobial Agents and Chemotherapy 8, 402-408.

Ogawara, H., Mantoku, A. \& Shimada, S. (1981). $\beta$-Lactamase from Streptomyces cacaoi. Purification and properties. Journal of Biological Chemistry 256, 2649-2655.

OKanishi, M., Suzuki, K. \& Umezawa, H. (1974). Formation and reversion of streptomycete protoplasts: cultural conditions and morphological study. Journal of General Microbiology 80, 389-400.

RighetTI, P. \& DRYSDALE, J. W. (1971). Isoelectric focusing in polyacrylamide gels. Biochemica et biophysica acta 236, 17-28.

Samraoui, B., Sutton, B. J., Todd, R. J., ARTYmiuk, P. J., Waley, S. G. \& Phillips, D. C. (1986). Tertiary structural similarity between a class $A \beta$ lactamase and a penicillin-sensitive D-alanyl-carboxy-peptidase-transpeptidase. Nature, London 320 , 378-380.

SouTHERN, E. H. (1975). Detection of specific sequences among DNA fragments separated by gel electrophoresis. Journal of Molecular Biology 98, 503-517. 